OPEN ACCESS

Edited by:

Juarez Antonio Simões Quaresma, Universidade do Estado do

Pará, Brazi

Reviewed by: Roberta Bruhn, Vitalant Research Institute, United States Ilaria Cavallari

Veneto Institute of Oncology (IRCCS), Italy

Anselmo Souza,

Federal University of Bahia, Brazi

*Correspondence Antonio Carlos R. Vallinoto vallinoto@ufpa.br

Specialty section

This article was submitted to Infectious Diseases - Surveillance, Prevention and Treatment, a section of the journal

Frontiers in Public Health

Received: 10 December 2021

Accepted: 10 January 2022

Published: 11 February 2022

Citation:

Abreu IN, Lopes FT, Lima CNC

Barbosa AdN, Oliveira $L R d$, Fujishima MA, Freitas FB, Santos MBd, Lima VNd, Cayres-Vallinoto IMV Castelo-Branco S, Silva HPd and Vallinoto ACR (2022) HTLV-1 and

HTLV-2 Infection Among Warao Indigenous Refugees in the Brazilian Amazon: Challenges for Public Health in Times of Increasing Migration.

Front. Public Health 10:833169. doi: 10.3389/fpubh.2022.833169

\section{HTLV-1 and HTLV-2 Infection Among Warao Indigenous Refugees in the Brazilian Amazon: Challenges for Public Health in Times of Increasing Migration}

\author{
Isabella Nogueira Abreu ${ }^{1}$, Felipe Teixeira Lopes ${ }^{1}$, Carlos Neandro Cordeiro Lima ${ }^{1}$, \\ Alexandre do Nascimento Barbosa ${ }^{2}$, Lehi Rodrigues de Oliveira ${ }^{2}$, \\ Mayumi Aragão Fujishima ${ }^{2}$, Felipe Bonfim Freitas ${ }^{3}$, Mike Barbosa dos Santos ${ }^{1}$, \\ Vitor Nina de Lima ${ }^{4}$, Izaura M. V. Cayres-Vallinoto ${ }^{1}$, Socorro Castelo-Branco ${ }^{2}$, \\ Hilton P. da Silva ${ }^{5}$ and Antonio Carlos R. Vallinoto ${ }^{1 *}$ \\ ${ }^{1}$ Laboratório de Virologia, Instituto de Ciências Biológicas, Universidade Federal do Pará, Belém, Brazil, ${ }^{2}$ Faculdade de \\ Medicina, Instituto de Ciências da Saúde, Universidade Federal do Pará, Belém, Brazil, ${ }^{3}$ Seção de Virologia, Instituto \\ Evandro Chagas, Ananindeua, Brazil, ${ }^{4}$ Secretaria de Saúde do Município de Belém (SESMA), Belém, Brazil, ${ }^{5}$ Programa de \\ Pós-Graduação em Antropologia e Programa de Pós-Graduação em Saúde, Ambiente e Sociedade na Amazônia, \\ Universidade Federal do Pará, Belém, Brazil
}

Introduction: Human T-lymphotropic virus (HTLV) infection is endemic in indigenous populations of the Americas. We describe herein the prevalence of HTLV-1 and HTLV-2 infection among Warao indigenous refugees from Venezuela living in Belém, Pará, Brazil.

Methods: In total, 101 individuals of both sexes (43 men and 58 women) between 18 and 77 years of age were investigated. Blood samples were collected and separated into plasma and leukocytes. Serological screening was performed using an enzyme-linked immunosorbent assay (ELISA; Murex HTLV-I+II, DiaSorin, Dartford, UK), and seropositive samples were submitted to proviral DNA extraction followed by real-time polymerase chain reaction (qPCR). A nested PCR of the env region (630 bp) followed by enzymatic digestion with Xhol was performed to identify the molecular subtype of HTLV-2, in addition to sequencing analysis of the 5'LTR-I and 5'-LTR-II regions.

Results: Of the 101 individuals analyzed, 3 (3.0\%) were seropositive. Molecular analysis of the pol and tax genes confirmed the HTLV-1 infection in a 55-year-old woman and HTLV-2 infection in a man (68 years old) and a woman (23 years old). HTLV-2 strains were defined by enzymatic digestion as belonging to the HTLV-2b subtype. The sequencing of the $5^{\prime}$ LTR regions confirmed the presence of subtype $2 \mathrm{~b}$ and identified HTLV- 1 as belonging to subtype $1 \mathrm{~A}$ (Cosmopolitan) and the Transcontinental subgroup. Among the infected patients, it was possible to conduct medical interviews with two individuals after delivery of the result. One patient with HTLV-2 reported symptoms such as joint pain, foot swelling, frequent headache, dizziness and lower back pain. The HTLV-1-positive woman was diagnosed with a tumor, dementia, urinary incontinence, felt body pain, and had spots on her body. The presence of the HTLV-2b subtype highlights the prevalence 
of this molecular variant among indigenous South Americans, as well as the presence of HTLV-1 Transcontinental, which has a worldwide distribution.

Conclusion: These results reveal a high prevalence of HTLV-1/2 infection among Warao immigrants, suggesting migratory flow as a virus spread mechanism among human populations and alert public authorities to the need to create epidemiological surveillance programs, public social and health policies aimed at welcoming immigrants in the Brazilian territory.

Keywords: migration, Warao, Venezuelans, Amazon, public health

\section{INTRODUCTION}

Human T-lymphotropic viruses 1 and 2 (HTLV-1 and HTLV2) are members of the Retroviridae family that infect humans and have numerous similarities in biological and molecular properties (1).

HTLV-1 infection has endemic characteristics in well-defined geographic regions such as southern Japan, the Caribbean, and Australia $(2,3)$, where the infection is associated with adult $\mathrm{T}$ cell leukemia (ATL), uveitis, and a chronic neurological disease known as HTLV-1-associated myelopathy (HAM). HTLV-1 infection is present with varying frequencies among American indigenous peoples, and its origin is attributed to the migratory flow of ancestors or, more recently, to the trafficking of African slaves during the colonial period (4).

HTLV-2 infection has an endemic distribution in Amerindian populations (5-7). In North America, HTLV-2 is present in the Navajo and Pueblo Indians of New Mexico $(8,9)$ and among the Seminoles in Florida (10). In Central America, the infection is endemic among the Guaymi of Panama (11-13) and Maya of Mexico (14). In South America, the infection has been described in the Wayu, Guahibo, Tunebo, and Orinoco of Colombia (1519), the Toba, Mataco, and Mapuche of Argentina (20-22), and Gran Chaco of Paraguay (22). In Brazil, the presence of HTLV2 is described as hyperendemic in several ethnic groups, with emphasis on the Kayapó people, where the prevalence reaches percentages above $30 \%$ in some villages, with the endemicity being associated with the spread of the virus through motherchild (by breastfeeding) and sexual transmission routes $(6,23)$.

Molecular studies demonstrate the circulation of three HTLV2 molecular subtypes among these different indigenous peoples of the Americas, with HTLV-2a and HTLV-2b (24) being prevalent among peoples of North, Central and South America $(13,14,19,22,25-27)$ and the HTLV-2c subtype restricted to indigenous peoples of the Brazilian Amazon (6, 7).

The origin of HTLV-2 infection among the native peoples of the Americas has been attributed mainly to the migratory flow of the Asian ancestors of the current Amerindian peoples who $\sim 30,000$ years ago migrated toward North America via the Bering Strait, with a subsequent descent toward Central and South America $(28,29)$. This migratory flow would have introduced subtypes $2 \mathrm{a}$ and $2 \mathrm{~b}$ among the current Amerindian peoples, with the exception of the native peoples of Brazil, whose $2 c$ variant seems to have evolved independently after the differentiated migration of ancestral peoples toward the Amazon $(7,30)$.

Past and current human migratory flows are important mechanisms for the dissemination, emergence and re-emergence of infectious agents in different geographic areas (28), having a marked role in the origin and spread of HTLV-1 and HTLV2 from the African continent toward Europe, Asia and the Americas (4, 29, 31). Currently, social, political and economic crises have motivated intense migratory movements and asylum requests in Latin American countries, which certainly favors the dispersion and emergence of infectious agents to new geographic areas. In this sense, in the present study, we investigated the occurrence of HTLV-1/2 infection and its subtypes in Venezuelan immigrants of the Warao ethnic group living as refugees in the city of Belém, one of the largest metropolises in the Brazilian Amazon, to alert public authorities to the need to create epidemiological surveillance programs, public social and health policies aimed at welcoming immigrants, and the adequate prevention of the spread of HTLV-1/2 in the Brazilian territory.

\section{METHODS}

\section{Warao Population}

The Warao people are the second most populous indigenous group in Venezuela. Originally, they were located predominantly in the Caribbean region of the Orinoco River Delta, in hundreds of communities dispersed in rural, riverside, and coastal areas and in several cities in the state of Delta Amacuro and regions of the states of Monagas and Sucre, with archaeological records of their presence in the area since 8 thousand years ago. The economic and ecological pressures on their territories have been ongoing for several decades, but they have become more acute in the last 10 years, leading the Warao people to seek refuge in other bordering countries $(32,33)$. They started to migrate to Brazil in mid-2014, with migration intensifying with the increase in the Venezuelan crisis in 2016, reaching the city of Belém (Pará, Brazil), as well as other Bazilian capitals the following years (Figure 1). The Warao migrated mainly in search of a better quality of life and were motivated by the political, economic and humanitarian crisis in their country. In Brazil, family groups ultimately reside in public or self-managed shelters or even live in street conditions and extreme poverty, often being exposed to drug trafficking and prostitution $(34,35)$. 


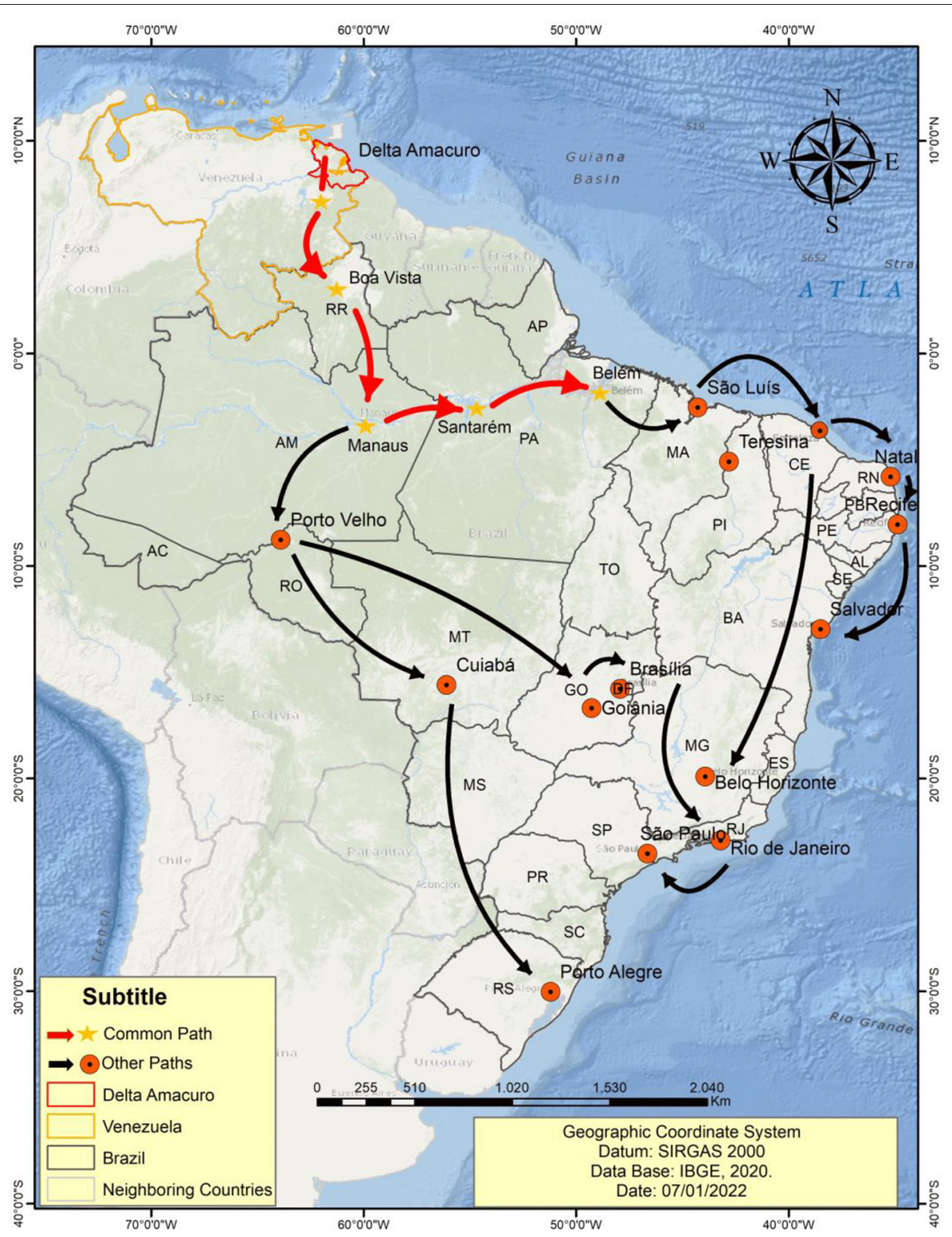

FIGURE 1 | Map representing the migratory flow of the Warao people from Venezuela to Belém (State of Pará) and other Brazilian capitals.

In Venezuela, the Warao had fishing, crafts and the collection of forest products as their main source of income. In their culture, women are responsible for taking care of the home, raising children and producing handicrafts sold in urban areas. In Brazil, they are also responsible for collecting money at traffic signals. Men, on the other hand, are responsible for feeding the family and building houses (33).

Culturally, they try to maintain the role assignments between men and women when they are refugees in other countries. However, due to differences in territories, they ultimately try other means of support. In some places, due to factors such as prejudice, xenophobia and the absence of public policies, indigenous Venezuelans are unable to enter the labor market and become involved in crime and prostitution (34-36).

\section{Ethical Aspects and Sample Collection}

A total of 101 whole-blood samples were obtained from individuals self-declared as belonging to the Warao ethnic group, all of whom were from Venezuela and were living in a refugee situation in the metropolitan region of Belém, Pará, Brazilian Amazon. The project's objectives were presented to the communities in Spanish and Warao, after which prior consent was obtained from the leaders to carry out the research. All volunteers were interviewed with the help of an interpreter, and after agreeing to participate in the research, they signed a free and informed consent term. The project followed the guidelines of the Declaration of Helsinki and was approved by the Ethics Committee for Research on Human Beings of the 
Health Sciences Institute of the Federal University of Pará (CAAE: 31800720.1.0000.0018).

Collections were carried out from September 2020 to January 2021. From all participants, $4.5 \mathrm{~mL}$ of venous blood was collected in a vacuum tube containing EDTA (ethylenediamine tetraacetic acid) as an anticoagulant. Then, the samples were transported to the Virology Laboratory of the Federal University of Pará in an insulated box. The samples were submitted to plasma and leukocyte separation by means of centrifugation at 8,000 rpm for $15 \mathrm{~min}$, followed by storage at $-20^{\circ} \mathrm{C}$ until analysis.

\section{Serological Screening}

The samples were submitted to serological screening for the detection of anti-HTLV-1 and anti-HTLV-2 antibodies using an enzyme-linked immunosorbent assay (ELISA; Murex HTLVI+II, DiaSorin, Dartford, UK).

\section{Real-Time PCR}

ELISA-positive samples were subjected to DNA extraction using a QIAamp DNA Mini and Blood Mini Handbook Kit (QIAGEN, Hilden, Germany).

qPCR was used to confirm and differentiate HTLV-1 and HTLV-2 infection. In each sample, the human albumin gene was used as an endogenous control, and the viral gene regions pol (186 bp) and tax (75 bp) (37) were amplified.

The samples were tested in triplicate using Applied Biosystems Step One Plus Real-Time PCR equipment. For each reaction, 12.5 $\mu \mathrm{L}$ of TaqMan Universal PCR Master Mix (2X), $6.0 \mu \mathrm{L}$ of ultrapure water $\left(\mathrm{H}_{2} \mathrm{O}\right), 0.5 \mu \mathrm{L}$ of each primer, $0.5 \mu \mathrm{L}$ of each probe and $5.0 \mu \mathrm{L}$ of DNA were used, resulting in a total volume of $25 \mu \mathrm{L}$. The following temperature cycles were used: $95^{\circ} \mathrm{C}$ for $10 \mathrm{~min}$, followed by 45 cycles of $95^{\circ} \mathrm{C}$ for $15 \mathrm{~s}$ and $60^{\circ} \mathrm{C}$ for binding of primers and probes for $1 \mathrm{~min}$.

The primers used were 5 -CCCTACAATCCAACCAG CTCAG-3' (HTLV-1F), 5' -GTGGTGAAGCTGCCATCG GGTTTT-3' (HTLV-1R), 5' -CGATTGTGTACAGGCCG ATTG-3' (HTLV-2F), 5' -CAGGAGGGCATGTCGATGTAG-3' (HTLV-2R), $5^{\prime}$-GCTGTCATCTCTTGTGGGCTGT-3' (Albumin F), and $5^{\prime}$-AAACTCATGGGAGCTGCTGGTT- $3^{\prime}$ (Albumin $\mathrm{R}$ ), and the probe sequences were FAM-5'-CTTTACT GACAAACCCGACCTACCCATGGA-3' -MGB (HTLV-1), FAM-5' -TGTCCCGTCTCAGGTGGTCTATGTTCCA-3' -MGB (HLTV-2) and FAM-5' -CCTGTCATGCCCACACAAATCTC$3^{\prime}$-MGB (Albumin) (37).

\section{Restriction Fragment Length Polymorphism}

Samples confirmed by qPCR as HTLV-2 positive were subjected to molecular subtype identification through a nested PCR of the env region $(630 \mathrm{bp})$, followed by enzymatic digestion using the restriction enzyme XhoI, which generates two fragments (430 and $180 \mathrm{bp}$ ). The first reaction consisted of $29.0 \mu \mathrm{L}$ of water (H2O), $5.0 \mu \mathrm{L}$ of buffer (10X), $1.5 \mu \mathrm{L}$ of $\mathrm{MgCl} 2(50 \mathrm{mM}), 0.5$ $\mu \mathrm{L}$ of primer (E2) 5' CTGCAGAAGCTAGCAGGTCTA-3' (20 pmol), $0.5 \mu \mathrm{L}$ primer (E5) 5 -AGCCAAGTGTCCCTTCGACTA$3^{\prime}(20 \mathrm{pmol}), 8.0 \mu \mathrm{L}$ of dNTPs $(1.25 \mathrm{mM}), 0.5 \mu \mathrm{L}$ of Taq $(1 \mathrm{U} / \mu \mathrm{L})$, and $5.0 \mu \mathrm{L}$ of DNA.
The second reaction followed the same protocol, using the primers (E1) 5' -CTGCAACAACTCCATTATCCT-3' and (E2) 5 ' CTGCAGAAGCTAGCAGGTCTA-3' and $5.0 \mu \mathrm{L}$ of DNA from the first reaction (24). Both reactions employed the same temperature cycles: $94^{\circ} \mathrm{C}$ for $3 \mathrm{~min}$ and 35 cycles of $94^{\circ} \mathrm{C}$ for $40 \mathrm{~s}$ for denaturation, $53^{\circ} \mathrm{C}$ for $30 \mathrm{~s}$ for annealing primers, and $72^{\circ} \mathrm{C}$ for $40 \mathrm{~s}$ for extension.

For enzymatic digestion with XhoI, $7.3 \mu \mathrm{L}$ of water $\left(\mathrm{H}_{2} \mathrm{O}\right)$, $2.0 \mu \mathrm{L}$ of RE Buffer (10X), 0.2 $\mu \mathrm{L}$ of BSA, $10.0 \mu \mathrm{L}$ of DNA from the second PCR and $0.5 \mu \mathrm{L}$ of the XhoI enzyme were incubated for $4 \mathrm{~h}$ at $37^{\circ} \mathrm{C}$. The products were submitted to $3 \%$ agarose gel electrophoresis at a voltage of $100 \mathrm{~V}$ for $40 \mathrm{~min}$ and visualized with ethidium bromide staining.

\section{Nested PCR of the $5^{\prime}$ Long Terminal Repeat Region}

The sample confirmed for HTLV-1 was subjected to amplification of the 5 LTR-1 region, with the aim of characterizing the molecular subtype. First, $11.45 \mu \mathrm{L}$ of ultrapure water $\left(\mathrm{H}_{2} \mathrm{O}\right), 1.25 \mu \mathrm{L}$ of buffer $(10 \mathrm{X}), 3.0 \mu \mathrm{L}$ of $\mathrm{MgCl}_{2}(50 \mathrm{mM})$, $6.0 \mu \mathrm{L}$ of dNTPs $(10 \mathrm{mM}), 0.5 \mu \mathrm{L}$ of each primer $(20$ pmol), $0.3 \mu \mathrm{L}$ of Taq $(1 \mathrm{U} / \mu \mathrm{L})$ and $2.0 \mu \mathrm{L}$ of DNA were combined. The following HTLV-1 primer sequences were used: (LTR-I.01) 5' -TGACAATGACCATGAGCCCCAA-3', (LTR-I.02) 5' -CGCGGAATAGGGCTAGCGCT-3' , (LTR-I.03) $5^{\prime}$-GGCTTAGAGCCTCCCAGTGA-3', and (LTR-I.04) $5^{\prime}$ GCTAGGGAATAAAGGGGCGC-3'. For HTLV-2, (F-IILTR) $5^{\prime}$-TCGCGATGACAATGGCGACTAGCCTC-3', (Long-Gag) 5'-GGGGGCTTTGGGTATTGGAGTTGGG-3', (Mo16) $5^{\prime}$-GCCTCCCAAGCCAGCCAC-3', and (MSW-Gag) $5^{\prime}$ GGGAAAAGCCCGTGGATTTGCCCCAT-3' were used. The following temperature cycle was used: $94^{\circ} \mathrm{C}$ for $5 \mathrm{~min}$; 35 cycles at $94^{\circ} \mathrm{C}$ for $40 \mathrm{~s}, 62^{\circ} \mathrm{C}$ for $30 \mathrm{~s}$ and $72^{\circ} \mathrm{C}$ for $40 \mathrm{~s}$; ending at $72^{\circ} \mathrm{C}$ for $10 \mathrm{~min}$.

\section{DNA Sequencing and Phylogenetic Analysis}

After purification of the PCR product (5'LTR region), the amplified DNA was sequenced using the Sanger method with a BigDye Terminator v3.1 Cycle Sequencing Kit (Thermo Fisher, Waltham, MA, USA) using Genetic Analyzer 3130xl equipment (Applied Biosystems) (38).

Sequence alignment of $430 \mathrm{bp}$ for HTLV-1 and $534 \mathrm{bp}$ for HTLV-2 of the 5'LTR region was performed using the Clustal W program implemented in BioEdit software v7.1.9 (39). The phylogenetic relationships between the sequences described in the present study (HTLV-1 - BRPA_31564 and HTLV-2 BRPA_31238) and those available in GenBank for HTLV-1 (BRPA; 146, BRPA; 180, CQ443748; BS130, EU108721; CA422, CQ443755; K344, DQ005558; HTLV06, CQ443757; K535, D1005565; HTLV24, M37299; H5, U12804; Algerian, U12806; Pr52 Moroccan, U12805; OD Mauritanian, and L76310; pyg19, JX501) and for HTLV-2 (AF306735; BrBel, AF306734; BrBel, AF306725; BrBel, AF306726; BrBel, U10253; Br, AF306733; BrPa Kararao, L42509; Br Kayapo, L42508; Br Kayapo, AF306731, BrPa Kararao, AF306730; BrPa Tira; BrPa Kararao, AF306724; BrBel, 
AF306728; BrPa Gorotire, AF306727; BrPa Gorotire, AF306729; BrPa Tiriyo, L42507; Ghana, L42510; Mex, U10257; USA, Z46838; Afr, U10256; USA, U1060; USA, M10060, U10252; USA, U10258; Nor, Y14364; Bambuti Afr, HTLVII_Y13051; Gab, L207; USA, Z46888; Afr, U10263; USA, U12794; Wayu Col, U10260; USA, U10264; USA, U10261; USA, L11456; Guay mi, U12792; Wayu Col, X89270; Ita, U10255; ItA, L77241; Esp, L77237; Esp, U10254; Ita, U10259; USA, L77244; Esp, L77238, Esp, U10265, Esp, L77236; Esp, L77235; Esp, and U10266; Esp) were inferred by the Bayesian method in the program MrBayes v3.2.7 (40), using the replacement Hasegawa-Kishino-Yano (HKY) models for HTLV-1 and the GTR+G model for HTLV-2 in the program JmodelTest v2.1.10 (41). The statistical reliability of the Bayesian tree was evaluated using 1,000 bootstrap replicates and visualized using the FigTree v1.4.4 program (42).

\section{RESULTS}

\section{Serological and Molecular Analysis}

Among the 101 samples analyzed, the mean age of the participants was 36 years, ranging between 18 and 77 years. Three individuals (3.0\%) tested positive by ELISA. Afterward, the infection was confirmed by characterizing of the viral type in the samples by means of qPCR analysis for the pol and tax genes.

HTLV-1 infection was confirmed in a 55-year-old woman (1\%), and HTLV-2 was present in a man (68 years old) and in a woman ( 23 years old) (2.0\%). Of the three positive samples, it was possible to amplify the $5^{\prime}$ LTR regions in only two for subsequent sequencing and phylogenetic analysis.

The sample characterized as HTLV-1 positive showed, in the phylogenetic tree, $100 \%$ grouping with samples of the Cosmopolitan subtype (HTLV-1a), Transcontinental subgroup (A) (Figure 2).

The HTLV-2 detected in one of the samples grouped in the phylogenetic tree, with $76 \%$ support, with samples belonging to the HTLV-2b subtype (Figure 3), forming a clade with 95\% identity with strains isolated from the Guaymi (L11456) and Wayu (U12792) indigenous communities from Colombia. Although it was not possible to perform amplification and sequencing of the 5'LTR region in one of the HTLV-2-infected samples, nested PCR of the env region followed by enzymatic digestion with XhoI confirmed that the sample also belonged to subtype $2 \mathrm{~b}$.

\section{Clinical-Epidemiological Characterization of HTLV-1/2-Seropositive Individuals}

As part of the Screening and Counseling Program for People Living with HTLV implemented by the UFPA Virology Laboratory, the results of the serological screening and molecular confirmation were delivered to all participants.

The three individuals positive for the infection were evaluated by a physician from the Belém Municipal Health Department for individual monitoring by the Unified Health System (SUS), at which time a consultation and interview were carried out to obtain information on risk factors and signs/symptoms associated with HTLV infection (Table 1).

\section{Individual \#31564 (HTLV-1)}

The individual is female, 55 years old, and single; has lived in Brazil for 4 years; is illiterate and unemployed; and earns less than half the national minimum wage per month (U\$200). She did not have tattoos or piercing, reported not knowing about receiving blood transfusions, and reported having 25 children who were breastfed for more than 6 months. She was breastfed as a child. She refused to answer whether she had had sex with a sex worker during her lifetime or if she had been sexually abused. She stated that she did not use condoms during sexual intercourse and did not remember the age of first sexual intercourse.

The patient had a central nervous system tumor identified by $\mathrm{CT}$ at the health service, reported going to the bathroom more frequently than usual, felt pain in her body, was progressing to dementia, and had spots on her arm.

\section{Individual \#31235 (HTLV-2)}

The individual was male and 68 years old, lived together with his partner and had resided in Brazil for 3 years. He could read and write Spanish, but he had incomplete basic education, was unemployed, received emergency aid from the government, and earned $\sim 1$ national minimum wage per month. He reported having been a smoker but had quit a long time ago. He did not drink alcohol, had a tattoo located on his arm, reported that he had never received a blood transfusion, had never used illegal drugs, was breastfed as a child, had his first sexual intercourse at age 20 , had a steady sexual partner, did not use a condom during sexual relations, had never had sex with a sex worker and reported never having been sexually abused.

During the clinical evaluation, he reported having dizziness, frequent headache, joint pain, lower back pain and a swollen foot with spots for more than 1 year.

\section{Individual \#31238 (HTLV-2)}

The individual was female and 23 years old, had lived in Brazil for 1 year, lived with her partner, knew how to read and write in Spanish, had incomplete basic education, and was unemployed with a family income between half and one national minimum wage per month.

Upon delivery of the result and interview with the physician for information about the presence of signs and symptoms, the patient refused to receive the result.

\section{DISCUSSION}

In the present study, we identified the presence of HTLV-1 and HTLV-2 infections in Warao immigrant refugees in Belém, capital of the State of Pará. There are few studies on the prevalence of HTLV-1/2 infection in Venezuela, with emphasis by León et al. (43) on blood donors, in which an occurrence of $0.2 \%$ was detected, by Márquez et al. (44) on patients seen at a health care unit $(0.58 \%)$ and on indigenous populations, in which the prevalence of HTLV-2 subtype b infection was described as $61 \%$ in the Yaruro and Guahibo populations (45), which once again reinforces the presence of high frequencies of HTLV-2 infection in South American indigenous populations. 


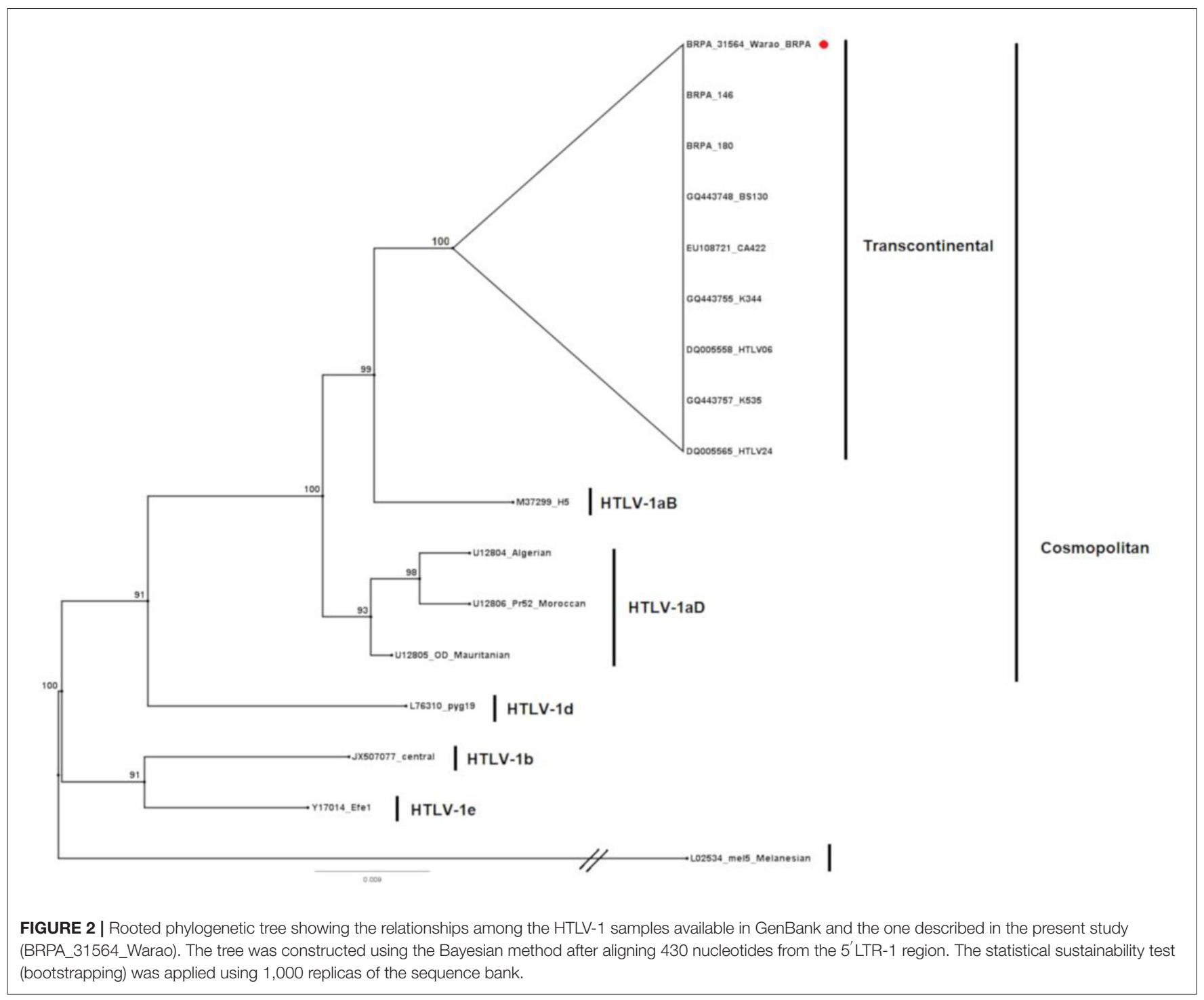

The first description of HTLV-2 in Venezuelan indigenous peoples occurred in 1993 in the Pumé ethnic group, with 5\% of the samples being positive for HTLV-2. Perez et al. (46) found this prevalence when investigating two villages that had greater contact with non-indigenous individuals and four more isolated villages, describing the presence of the infection as something restricted to individuals who maintained contact with outsiders, suggesting a non-indigenous origin of the virus. The $3 \%$ prevalence observed in our study is close to that described for HTLV-2 among the Pumé, especially due to the character of a non-isolated population that the Warao present in the current context.

On the other hand, the description of the presence of HTLV-1 in the present study diverges from the three previous studies that investigated the seroprevalence for HTLV-1/2 in Venezuela (4648). Notably, the presence of HTLV-1 subtype Cosmopolitan, Transcontinental subgroup, suggests the circulation of HTLV-1 among the Warao, perhaps as a result of a possible transmission from increased contact with non-indigenous individuals, as suggested by Vandamme et al. (4) regarding contacts with African-descendant populations living in the Americas.

Studies revealing a high prevalence of HIV-1 (9.55\%) in Warao have also indicated a high probability of HTLV infection in this population since transmission routes and risk factors are common for these and other sexually transmitted infections (STIs) $(48,49)$.

The Warao refugee population in Brazil is looking for better living conditions, such as work and access to the education and health system. However, they ultimately live in precarious situations, living in makeshift shelters and facing situations of great social and economic vulnerability, commonly becoming victims of racism, other forms of discrimination and the absence of public policies that are culturally sensitive to their needs as indigenous people and refugees $(35,50)$. All of these aspects represent risk factors, with several reports of sexual abuse, drug use and sex in exchange for money (49). 


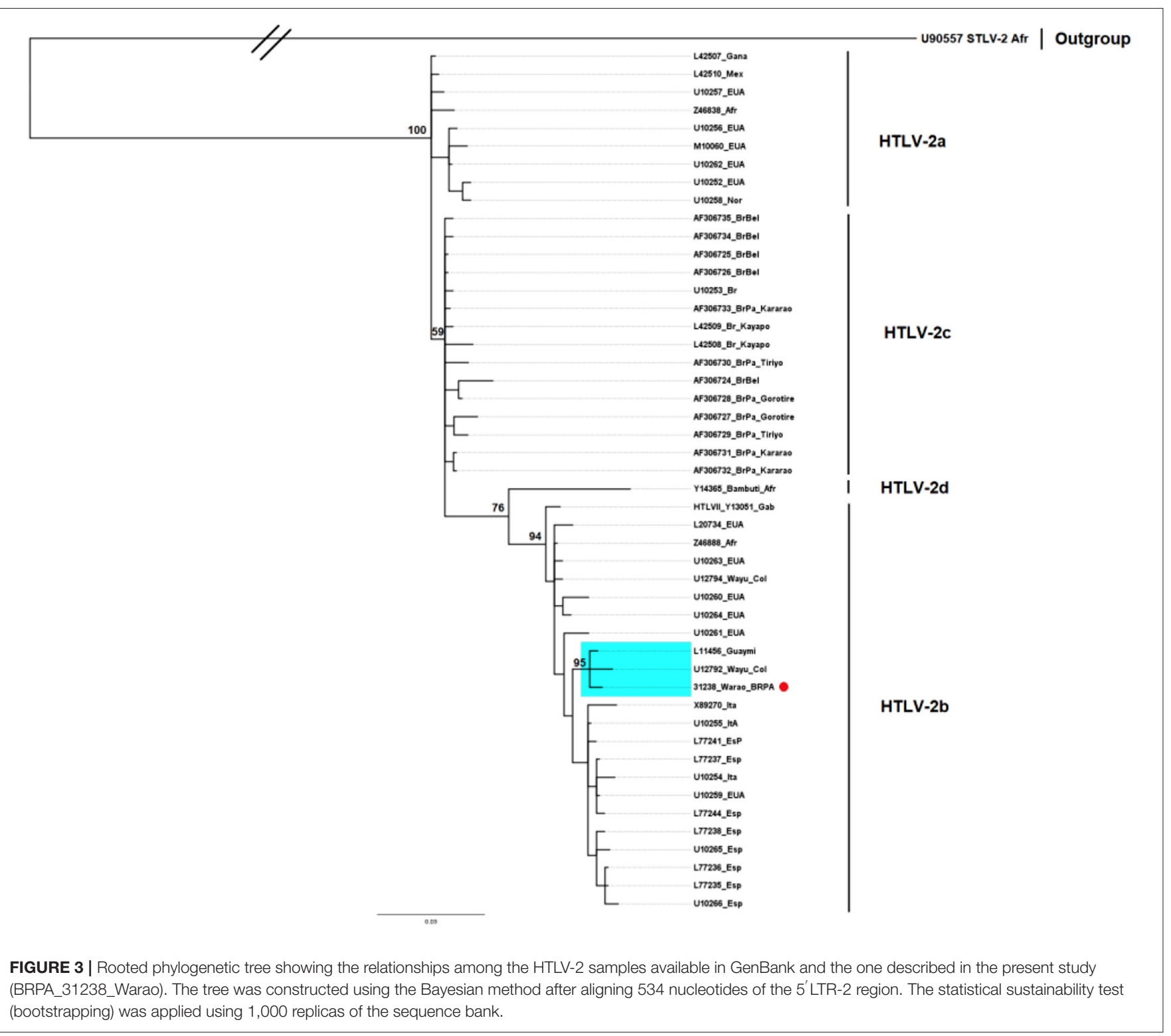

TABLE 1 | Epidemiological characteristics of HTLV-positive individuals belonging to the Warao ethnic group residing in the city of Belém, Pará, Brazil.

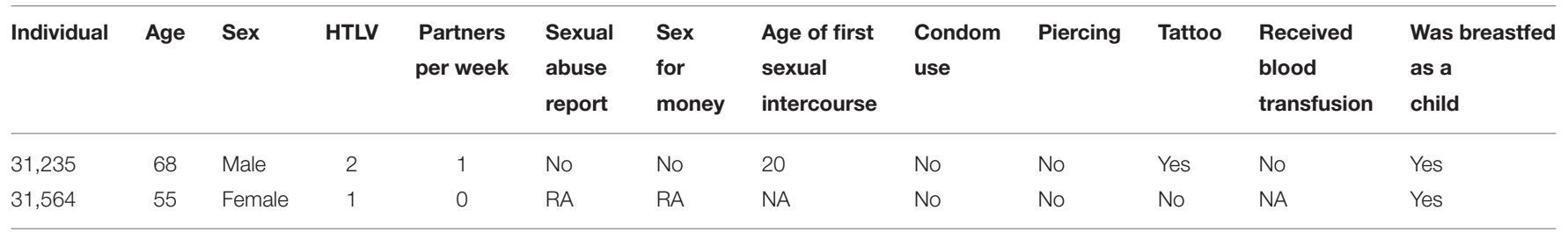

RA, refused to answer; NA, could not answer.

In our study, the occurrence of HTLV-1 and HTLV-2 in two females is perhaps associated with a greater exposure of women to a situation of risk for STIs due to the living conditions faced by these indigenous communities, where women are subordinate to men, resulting in cases of sexual abuse, family violence and risky sexual practices (35).
To date, the results described here are unprecedented and reinforce the findings of the high prevalence of HTLV-2 in indigenous peoples, as already demonstrated by our group in populations from the Brazilian Amazon (6, 23, 30, 51). However, the presence of the HTLV-2b subtype represents a unique aspect in the epidemiological context of HTLV infection in the city of 
Belém, where the HTLV-2c subtype, frequent in the indigenous peoples of the region, prevails. Furthermore, the presence of subtype $2 \mathrm{~b}$ was described only once in the capital Belém, and although it was not possible to clarify the entry route at that time, it was most likely the result of introduction by migratory flow (52). More recently, the same molecular subtype $2 \mathrm{~b}$ was described among injection drug users in the State of Pará (53), reinforcing the need to implement molecular epidemiological surveillance to prevent the entry and spread of new viral strains in the population.

One of the hypotheses to explain the presence of HTLV-2b in the Warao people would be the proximity of their place of origin to the Guahibo people, in addition to the similar life habits (35). During the collections and interviews, it was possible to observe that there were, among the Warao residents in Belém, cases of union between individuals of different ethnicities and with non-indigenous individuals, suggesting possible alternative routes for the presence of the virus in the studied group. Another hypothesis would be that of sexual transmission through women who end up having a greater degree of exposure to harassment in large cities as a result of the sale of handicrafts or the act of asking for money at traffic signals. Similarly, for men, the risk is increased due to involvement with sex workers.

The sexual route being the main HTLV transmission route in the Warao population was supported by reports of not using condoms during sexual intercourse, increasing the susceptibility to STIs. Additionally, this hypothesis is reinforced by the precarious situation in which the Warao live, reporting lack of food, child malnutrition, and cases of pneumonia, tuberculosis, measles, coronavirus disease 2019 (COVID-19) and other diseases such as HIV and other STIs $(35,54,55)$.

HTLV-1 infection is associated with neurological symptoms that can affect between 1 and 5\% of those infected, especially affecting middle-aged women (56). In the clinical evaluation that HTLV-positive individuals underwent, it was possible to verify the occurrence of skin changes, body aches, urinary incontinence, dementia and diagnosis of a brain tumor in the 55-year-old patient with HTLV-1.

\section{CONCLUSION}

Finally, our results reveal for the first time the circulation of HTLV-1 and HTLV-2 in the Warao ethnic group from Venezuela, who are refugees in the State of Pará (northern Brazil). The presence of the HTLV-2b subtype reinforces that this molecular variant is prevalent among the indigenous peoples of South America and highlights migratory flow as an important means of introduction and dispersion of HTLV in human populations, especially those in the Brazilian Amazon. Due to the economic, political, environmental and humanitarian crises that several countries in Latin America are experiencing, resulting in intense migratory flows that mainly affect the most vulnerable groups, national states need to plan and implement culturally sensitive public health policies to welcome and care for traditional peoples in their territories, as well as guarantee adequate epidemiological surveillance and health services (among others) for immigrants, following multilateral legal provisions and the principles of humanitarian assistance and international solidarity.

\section{DATA AVAILABILITY STATEMENT}

The datasets presented in this article are not readily available for reasons related to data confidentiality and participant privacy. Requests to access the datasets should be directed to Prof. Antonio Carlos R. Vallinoto (vallinoto@ufpa.br).

\section{ETHICS STATEMENT}

The studies involving human participants were reviewed and approved by Human Research Ethics Committee of the Health Sciences Institute of the Federal University of Pará (CAAE: 31800720.10000.0018). The patients/participants provided their written informed consent to participate in this study.

\section{AUTHOR CONTRIBUTIONS}

AV, SC-B, and HS conceived and designed the study. IA, CL, FL, $\mathrm{FF}$, and MS performed the laboratory experiments. IA, CL, MF, $\mathrm{LO}$, and $\mathrm{AB}$ carried out sample collection. VL conducted field medical monitoring. IA, AV, and HS wrote the manuscript. All authors read and approved the final manuscript.

\section{FUNDING}

This study was funded by the National Council for Scientific and Technological Development (CNPQ \#442522/2019-3 and \#301869/2017-0), the Federal University of Pará (PAPQ/2021), and the Amazon Foundation for Studies and Support Research in Pará (FAPESPA).

\section{ACKNOWLEDGMENTS}

The authors thank the Warao population residing in Belém (PA) for participating in the study, the Federal University of Pará, the Evandro Chagas Institute, and the Municipal Health Department for supporting this study and FUNPAPA. We would like to thank Mr. João Victor Paixão de Sousa Ferreira for designing the map.

\section{REFERENCES}

1. Hall WW, Kubo T, Ijichi S, Takahashi H, Zhu SW. Human T cell leukemia/lymphoma virus, type II (HTLV-II): emergence of an important newly recognized patoghen. Semin Virol. (1994) 5:2. doi: 10.1006/smvy.1994.1017
2. Einsiedel L, Woodman RJ, Flynn M, Wilson K, Cassar O, Gessain A. Human T-Lymphotropic Virus type 1 infection in an indigenous Australian population: epidemiological insights from a hospital-based cohort study. BMC Public Health. (2016) 16:787. doi: 10.1186/s12889-016-3366-5

3. Sagara Y, Iwanaga M, Morita M, Sagara Y, Nakamura H, Hirayama H, et al. Fine-scale geographic clustering pattern of human T-cell leukemia virus type 1 
infection among blood donors in Kyushu-Okinawa, Japan. J Med Virol. (2018) 90:10. doi: 10.1002/jmv.25239

4. Vandamme AM, Hall WW, Lewis MJ, Goubau P, Salemi M. Origins of HTLV-1 in South America. Nat Med. (2000) 6:3. doi: 10.1038/73023

5. Maloney EM, Biggar RJ, Neel JV, Taylor ME, Hahn BH, Shaw GM, et al. Endemic human T cell lymphotropic virus type II infection among isolated Brazilian Amerindians. J Infect Dis. (1992) 166:1. doi: 10.1093/infdis/166.1.100

6. Ishak R, Harrington-Junior WJ, Azevedo VN, Eiraku N, Ishak MO, Guerreiro JF, et al. Identification of human T cell lymphotropic virus type iia infection in the Kayapo, an indigenous population of Brazil. AIDS Res Hum Retroviruses. (1995) 11:7. doi: 10.1089/aid.1995.11.813

7. Vallinoto AC, Ishak MO, Azevedo VN, Vicente ACP, Otsuki K, Hall WW, et al. Molecular epidemiology of human T-lymphotropic virus type II infection in Amerindian and urban populations of the Amazon region of Brazil. Hum Biol. (2002) 74:5. doi: 10.1353/hub.2002.0059

8. Hjelle B, Mills R, Swenson S, Mertz G, Key C, Allen S. Incidence of hairy cell leukemia, mycosis fungoides, and chronic lymphocytic leukemia in first known HTLV-II-endemic population. J Infect Dis. (1991) 163:3. doi: 10.1093/infdis/163.3.435

9. Hjelle B, Zhu SW, Takahashi H, Ijichi S, Hall WW. Endemic human $\mathrm{T}$ cell leukemia virus type II infection in southwestern US Indians involves two prototype variants of virus. J Infect Dis. (1993) 168:3. doi: 10.1093/infdis/168.3.737

10. Levine PH, Jacobson S, Elliott R, Cavallero A, Colclough G, Dorry C, et al. HTLV-II infection in Florida Indians AIDS. Res Hum Retroviruses. (1993) 9:2. doi: 10.1089/aid.1993.9.123

11. Heneine W, Kaplan JE, Gracia F, Lal R, Roberts B, Levine PH, et al. HTLVII endemicity among Guaymi Indians in Panama. N Engl J Med. (1991) 324:8. doi: 10.1056/NEJM199102213240815

12. Lairmore MD, Jacobson S, Gracia F, De BK, Castillo L, Larreategui M, et al. Isolation of human T-cell lymphotropic virus type 2 from Guaymi Indians in Panama. Proc Natl Acad Sci USA. (1990) 87:22. doi: 10.1073/pnas.87. 22.8840

13. Pardi D, Switzer WM, Hadlock KG, Kaplan JE, Lal RB, Folks TM. Complete nucleotide sequence of an Amerindian human T-cell lymphotropic virus type II (HTLV-II) isolate: identification of a variant HTLV-II subtype b from a Guaymi. Indian J Virol. (1993) 67:8. doi: 10.1128/jvi.67.8.4659-4664.1993

14. Gongora-Biachi RA, Lal RB, Rudolph DL, Castro-Sansores C, GonzalezMartinez P. Pavia-Ruz N. Low prevalence of HTLV-II in Mayan Indians in the Yucatan Peninsula, Mexico. Arch Med Res. (1997) 28:555-8.

15. Zaninovic V, Sanzon F, Lopez F, Velandia G, Blank A, Blank M, et al. Geographic independence of HTLV-I and HTLV-II foci in the Andes highland, the Atlantic coast, and the Orinoco of Colombia AIDS. Res Hum Retroviruses. (1994) 10:1. doi: 10.1089/aid.1994.10.97

16. Dueńas-Barajas E, Bernal JE, Vaught DR, Briceño I, Durán C, Yanagihara $\mathrm{R}$, et al. Coexistence of human T-lymphotropic virus types I and II among the Wayuu Indians from the Guajira Region of Colombia AIDS. Res Hum Retroviruses. (1992) 8:11. doi: 10.1089/aid.1992.8.1851

17. Duenas-Barajas E, Bernal JE, Vaught DR, Nerurkar VR, Sarmiento $\mathrm{P}$, Yanagihara $\mathrm{R}$, et al. Human retroviruses in Amerindians of Colombia: high prevalence of human $\mathrm{T}$ cell lymphotropic virus type II infection among the Tunebo Indians. Am J Trop Med Hyg. (1993) 49:6. doi: 10.4269/ajtmh.1993.49.657

18. Fujiyama C, Fujiyoshi T, Miura T, Yashiki S, Matsumoto D, Zaninovic $\mathrm{V}$. et al. A new endemic focus of human $\mathrm{T}$ lymphotropic virus type II carriers among Orinoco natives in Colombia. J Infect Dis. (1993) 168:4. doi: 10.1093/infdis/168.4.1075

19. Switzer WM, Owen SM, Pieniazek DA, Nerurkar VR, Duenas-Barajas E, Heneine W, et al. Molecular analysis of human T-cell lymphotropic virus type II from Wayuu Indians of Colombia demonstrates two subtypes of HTLV-Iib. Virus Genes. (1995) 10:2. doi: 10.1007/BF01702596

20. Biglione M, Gessain A, Quiruelas S, Fay O, Taborda MA, Fernandez E, et al. Endemic HTLV-II infection among Tobas and Matacos Amerindians from north Argentina. J Acquir Immune Defic Syndr (1988). (1993) 6:631-3.

21. Medeot S, Nates S, Recalde A, Gallego S, Maturano E, Giordano M, et al. Prevalence of antibody to human T cell lymphotropic virus types $1 / 2$ among aboriginal groups inhabiting northern Argentina and the Amazon region of Peru. Am J Trop Med Hyg. (1999) 60:4. doi: 10.4269/ajtmh.1999.60.623
22. Ferrer JF, Esteban E, Dube S, Basombrio MA, Segovia A, Peralta-Ramos M, et al. Endemic infection with human $\mathrm{T}$ cell leukemia/lymphoma virus type IIB in Argentinean and Paraguayan Indians: epidemiology and molecular characterization. J Infect Dis. (1996) 174:5. doi: 10.1093/infdis/174.5.944

23. Braço ILJ, de Sá KSG, Waqasi M, Queiroz MAF, Silva ANR, Cayres-Vallinoto IMV. et al. High prevalence of human T-lymphotropic virus 2 (HTLV-2) infection in villages of the Xikrin tribe (Kayapo), Brazilian Amazon region. BMC Infect Dis. (2019) 19:1. doi: 10.1186/s12879-019-4041-0

24. Hall WW, Takahashi H, Liu C, Kaplan MH, Scheewind O, Ijichi S, et al. Multiple isolates and characteristics of human T-cell leukemia virus type II. J Virol. (1992) 66:2456-63. doi: 10.1128/jvi.66.4.2456-2463.1992

25. Ijichi S, Tajima K, Zaninovic V, Leon-S FE, Katahira Y, Sonoda S, et al. Identification of human $\mathrm{T}$ cell leukemia virus type IIb infection in the Wayu, an aboriginal population of Colombia. Jpn J Cancer Res. (1993) 84:12. doi: 10.1111/j.1349-7006.1993.tb02824.x

26. Switzer WM, Pieniazek D, Swanson P, Samdal HH, Soriano V, Khabbaz RF, et al. Phylogenetic relationship and geographic distribution of multiple human T-cell lymphotropic virus type II subtypes. J Virol. (1995) 69:2. doi: 10.1128/jvi.69.2.621-632.1995

27. Miura T, Yamashita M, Zaninovic V, Cartier L, Takehisa J, Igarashi T, et al. Molecular phylogeny of human T-cell leukemia virus type I and II of Amerindians in Colombia and Chile. J Mol Evol. (1997) 44(Suppl. 1):S7682. doi: 10.1007/PL00000053

28. Ishak R, Machado LFA, Cayres-Vallinoto I, Guimarães Ishak MO, Vallinoto ACR. Infectious agents as markers of human migration toward the Amazon Region of Brazil. Front Microbiol. (2017) 8:1663. doi: $10.3389 /$ fmicb. 2017.01663

29. Ishak R, Guimarães Ishak MO, Azevedo VN, Machado LFA, Vallinoto IMC, Queiroz MAF, et al. HTLV in South America: origins of a silent ancient human infection. Virus Evol. (2020) 6:2. doi: 10.1093/ve/veaa053

30. Vallinoto ACR, Ishak R. HTLV-2: uma infecção antiga entre os povos indígenas da Amazônia brasileira. Rev Pan-Amaz de Saúde. (2017) 8:2. doi: 10.5123/S2176-62232017000200001

31. Van Dooren S, Salemi M, Vandamme AM. Dating the origin of the African human T-cell lymphotropic virus type-i (HTLV-I) subtypes. Mol Biol Evol. (2001) 18:4. doi: 10.1093/oxfordjournals.molbev.a003846

32. Silva HP, Miranda JCT, Lima VN. Desafios às Políticas de Saúde para Populações Tradicionais em Áreas Urbanas: O caso dos Indígenas Warao em Belém do Pará. In: Heufemann NEC, Ferla AA, Lima KMS, Martins FM, Lemos SM, editors. A Saúde Indígena no Brasil: educação, gestão e trabalho. (2020). p. 178-97.

33. Souza JH. Janokos Brasileiros: Uma Análise da Imigração dos Warao para o Brasil. Brasília: Boletim Científico ESMPU (2018). p. 71-99.

34. Souza MR. Políticas migratórias do Brasil. Os limites do programa de interiorização para indígenas Warao da Venezuela. [Trabalho de conclusão de curso]. [Foz do Iguaçu (PR)]: Universidade Federal da Integração LatinoAmericana. Instituto Latino-Americano de Economia, Sociedade e Política (Foz do Iguaçu: ILAESP) (2019).

35. Reichel-Dolmatoff G. La cultura material de los indios Guahibo. Revista del Instituto Etnológico Nacional (2013). Available online at: https://www.icanh. gov.co/index.php?idcategoria=8137 (accessed September 4, 2021).

36. González-Muñoz J. Etnia indígena Warao: visibilidad de los prejuicios occidentales contemporáneos hacia la ancestralidad. Serviço Social e Saúde. (2019) 18:2019. doi: 10.20396/sss.v18i0.8656931

37. Waters A, Oliveira AL, Coughlan S, de Venecia C, Schor D, Leite AC, et al. Multiplex real-time PCR for the detection and quantitation of HTLV-1 and HTLV-2 proviral load: addressing the issue of indeterminate HTLV results. $J$ Clin Virol. (2011) 52:1. doi: 10.1016/j.jcv.2011.05.022

38. Sanger F, Nicklen S. Coulson AR. DNA sequencing with chain-terminating inhibitors. Proc Natl Acad Sci USA. (1977) 74:5463-7. doi: 10.1073/pnas.74.12.5463

39. Hall TA. BioEdit: um editor de alinhamento de sequência biológica amigável e programa de análise para Windows 95/98/NT. Nucl Acids Symp Ser. (1999) 41:95-8.

40. Ronquist F, Teslenko M, Van Der Mark P, Ayres DL, Querida A, Hõhna S, et al. Huelsenbeck JP. MrBayes 32: efficient bayesian phylogenetic inference and model choice across a large model space. Syst Biol. (2012) 3:53949. doi: 10.1093/sysbio/sys029 
41. Darriba D, Taboada GL, Doallo R, Posada D. jModelTest 2: more models, new heuristics and parallel computing. Nat Methods. (2012) 9:772772. doi: $10.1038 /$ nmeth. 2109

42. Rambaut A. 2016-2012. FigTree Drawing Tool Version 1.4.0 Software. Institute of Evolutionary Biology, University of Edinburgh. Available online at: http:// tree.bio.ed.ac.uk/software/figtree/ (accessed November 5, 2021).

43. León G, Quirós AM, López JL, Hung M, Díaz AM, Goncalves J, et al. Seropositividad al virus linfotrópico de células $\mathrm{T}$ humanas tipos I y II en donantes del Banco Municipal de Sangre de Caracas y factores de riesgo asociados. Rev Panam Salud Publica. (2003) 13:11723. doi: 10.1590/S1020-49892003000200012

44. Márquez Y, Pimentel Z, Castillo S, Santiago M, Urdaneta J, Martínez A, et al. Frecuencia del Virus Linfotropico de Las Células T Humanas Tipo I/Ii en Pacientes que Asisten a la Unidad Programática Regional de Inmunología Clínica Del Estado Aragua, Venezuela, 2012. Saber. (2016) 28:83-9.

45. Leon-Ponte, Perez GE, Bianco N, Hengst J, Dube S, Love J. Endemic infection with HTLV-IIB in venezuelan Indians: molecular characterization. J Acquir Immune Defic Syndr Hum Retrovirol. (1998) 17:5. doi: 10.1097/00042560-199804150-00011

46. Perez GE, Leon-Ponte M, Noya O, Botto C, Gallo D, Bianco N. First description of endemic HTLV-II infection among venezuelan amerindians. $J$ Acquir Immune Defic Syndr. (1993) 6:1368-72.

47. Leon-Ponte M, Noya O, Bianco N, Echeverría de Perez G. Highly endemic human T-lymphotropic virus type II (HTLV-II) infection in a Venezuelan Guahibo Amerindian group. J Acquir Immune Defic Syndr Hum Retrovirol. (1996) 13:3. doi: 10.1097/00042560-199611010-00011

48. Villalba JA, Bello G, Maes M, Sulbaran YF, Garzaro D, Loureiro CL, et al. HIV-1 epidemic in Warao Amerindians from Venezuela: spatial phylodynamics and epidemiological patterns. AIDS. (2013) 27:11. doi: 10.1097/QAD.0b013e3283601bdb

49. Ponce P, Muñoz R, Stival M. Pueblos indígenas, VIH y políticas públicas en Latinoamérica: una exploración en el panorama actual de la prevalencia epidemiológica, la prevención, la atención y el seguimiento oportuno. Salud Colect. (2017) 13:3. doi: 10.18294/sc.2017.1120

50. De Macedo JN, Sousa Júnior OV, Biazussi HM, Pereira BG. Venezuelanos no Brasil: direitos dos Imigrantes e a Saúde Pública Local. Interfaces Cient Direito. (2019) 7:2. doi: 10.17564/2316-381X.2019v7n2p57-66

51. Ishak R, Vallinoto ACR, Azevedo VN, Lewis M, Hall WW, Ishak MOG. Molecular evidence of mother-to-child transmission of HTLV-IIc in the Kararao Village (Kayapo) in the Amazon Region of Brazil. Rev Soc Bras Med Trop. (2001) 34:6. doi: 10.1590/S0037-86822001000600004
52. Santos EL, Tamegão-Lopes B, Machado LF, Ishak MOG, Ishak R, Lemos JA, et al. Caracterização molecular do HTLV-1/2 em doadores de sangue em Belém, Estado do Pará: primeira descrição do subtipo HTLV-2b na região Amazônica. Rev Soc Bras Med Trop. (2009) 42:3. doi: 10.1590/S0037-8682200900030 0007

53. Oliveira-Filho AB, Araújo APS, Souza APC, Gomes CM, Silva-Oliveira GC, Martins LC, et al. Human T-lymphotropic virus 1 and 2 among people who used illicit drugs in the state of Pará, northern Brazil. Sci Rep. (2019) 9:14750. doi: 10.1038/s41598-019-51383-7

54. ACNUR. Agência da ONU para refugiados. Os Warao no Brasil. Contribuições da antropologia para a proteção de indígenas refugiados e migrantes. (2021). Brasília: UNHCR/ACNUR. Availabel onlie at: https://www.acnur.org/ portugues/wp-content/uploads/2021/04/WEB-Os-Warao-no-Brasil.pdf (accessed September 4, 2021).

55. Silva HP, Abreu IN, Lima CNC, Lima ACR, Barbosa AN, Oliveira LR, et al. Migration in times of pandemic: SARS-CoV-2 infection among the Warao indigenous refugees in Belém, Pará, Amazonia, Brazil. BMC Public Health. (2021) 21:1659. doi: 10.1186/s12889-021-11696-7

56. Carod-Artal FJ, Mesquita HM, Ribeiro LS. Manifestaciones neurológicas y discapacidad en pacientes que padecen mielopatía asociada al HTLV-I. Neurología. (2008) 23:78-84.

Conflict of Interest: The authors declare that the research was conducted in the absence of any commercial or financial relationships that could be construed as a potential conflict of interest.

Publisher's Note: All claims expressed in this article are solely those of the authors and do not necessarily represent those of their affiliated organizations, or those of the publisher, the editors and the reviewers. Any product that may be evaluated in this article, or claim that may be made by its manufacturer, is not guaranteed or endorsed by the publisher.

Copyright (C) 2022 Abreu, Lopes, Lima, Barbosa, Oliveira, Fujishima, Freitas, Santos, Lima, Cayres-Vallinoto, Castelo-Branco, Silva and Vallinoto. This is an open-access article distributed under the terms of the Creative Commons Attribution License (CC $B Y)$. The use, distribution or reproduction in other forums is permitted, provided the original author(s) and the copyright owner(s) are credited and that the original publication in this journal is cited, in accordance with accepted academic practice. No use, distribution or reproduction is permitted which does not comply with these terms. 